\title{
Analysis of Factors Affecting Firm Value in Property, Real Estate and Building Construction Companies Listed on the Indonesia Stock Exchange for the 2014-2018 Period
}

\author{
Marselia Purnama ${ }^{1)}$ \\ marselia.purnama@ubd.ac.id \\ Vivin Hanitha ${ }^{2)}$ \\ vivin.hanitha@ubd.ac.id \\ Adrian Hidayat ${ }^{3)}$ \\ adrian.hidayat@ubd.ac.id
}

\section{1) 2) 3) Buddhi Dharma University, Indonesia, Banten}

\begin{abstract}
This research was conducted at companies engaged in the property, real estate \& building construction sector which are listed on the Indonesia Stock Exchange.

In this study using purposive sample method as a sampling method. The number of samples used was 6 companies with research data conducted from 2014 to 2018 so that 30 observational data were obtained. In testing the hypothesis in this study carried out in six ways, namely the regression model test, classical assumption test, multiple linear regression analysis, partial test ( $t$ test), simultaneous test (f test), and test the coefficient of determination.

From the results of this study it can be concluded that simultaneously all variables have a significant effect on firm value. The results of the regression analysis show an adjusted value of 0.486599 , which means that the variation of Current Ratio, Debt to Equity Ratio, Net Profit Margi, Return on Equity and Earning per Share can explain $48.66 \%$ of the variation in firm value. While the remaining $51.34 \%$ is explained by other variables not examined in this study.
\end{abstract}

Keywords: Company Value, Property, Financial Ratios. 


\section{Preliminary}

In today's times, it is important for us to invest, because investment is our way of fighting inflation. There is a lot of stigma circulating in society that stocks are a gamble to test luck. When in fact, stocks are not gambling but proof of our ownership of a company. With the shares that we have, we become part of the owners of the companies whose shares we own. Some people call it gambling, because that person doesn't know how to calculate and determine the value of a company.

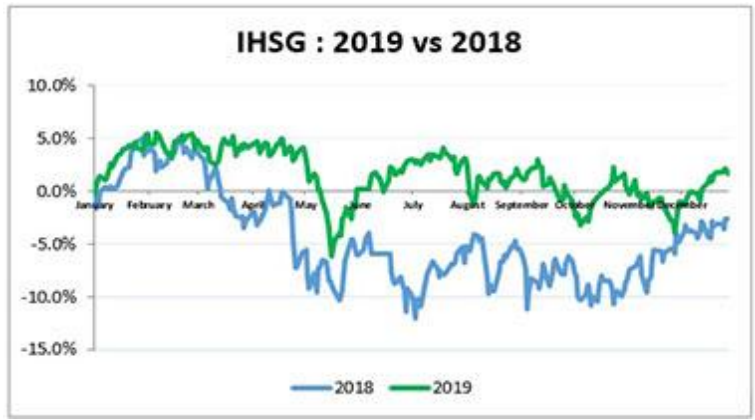

Figure 1

IHSG 2019 vs 2018

Source: https://www.indonesiare.co.id

Based on the JCI chart above, JCI performance is still promising in 2019. Therefore, a stock investor must be able to analyze the company's performance in depth, which can be seen from the company's financial statements, namely by using financial ratios in carrying out this analysis. Financial ratios tend to be easy to calculate and are very important to assess a company's financial condition. According to the intended use, financial ratios are divided into several types, namely liquidity ratios, solvency ratios or long-term liquidity ratios, efficiency ratios, profitability ratios, and market value ratios. Types of financial ratios can be used to assess the performance of a company.

Firm value is the investor's perception of the company's success rate which is often associated with the company's stock price. Some examples of ratios that can be easily understood by novice investors are current ratio, debt to equity ratio, net profit margin, return on equity, and earnings per share. These ratios are part of the type of financial ratios, using these ratios, investors can find out whether the company's performance has increased or decreased from the previous period. It can also affect firm value, because company performance reflects firm value.

Firm value can be measured using the company's valuation ratio using the company's stock price, the valuation ratios that can be used include Price Earning Ratio, Price to Book Value, and Tobin's Q. In this study the authors used Price to Book Value to measure firm value. . Based on the above background, the researcher is interested in raising this problem to conduct a study with the title "Analysis of Factors Affecting Firm Value in Property, Real Estate and Building Construction Companies Listed on the Indonesia Stock Exchange for the 2014-2018 Period"

\section{Theoretical basis}

Finance is a way of learning how to know how to do individual business, improve organization, allocate, use monetary resources over time, and also calculate risks in running the business. Therefore, a financial manager must be able to manage and assess a company's finances properly and correctly. Financial statement analysis is a process that is thoughtfully in order to help evaluate the current and past financial position and results of activities of a company, with the main objective of determining the most likely estimates and predictions regarding the condition and performance of the company in the future. 
Current ratio is a ratio that calculates the company's ability to pay off all short-term liabilities using its current assets. According to (Purnama 2020,19) said that "Debt to equity ratio (DER) is a ratio to measure the ratio between all debt and all capital owned by a company. "The debt to equity ratio shows the higher the level of leverage, the higher the risk borne by the company owner. According to Hery (2015) in (Purnama M. 2019, 121) says that: "Net profit margin is a ratio used to measure the percentage of net profit on net sales." Net profit margin measures a company's ability to generate net profit from sales. Return On Equity is a ratio to calculate the level of company profitability by comparing net profit after tax with the capital owned by the company. The Earning Per Share ratio measures how much the company's net income is contained in every single share outstanding.

The appraisal ratio is the most comprehensive measure of performance for a company. The variables Current Ratio, Debt to Equity Ratio, Net Profit Margin, Return on Equity, and Earning per Share are independent variables (free) while the Company Value using Price to Book Value is the dependent variable(Andy, 2018).

Firm value is an assessment of the current and future success of the company in the eyes of investors, which is reflected in the company's stock price. Market to book ratio / price to book value is an important ratio in calculating company value. This ratio describes the valuation of the price per share compared to the book value per share.

\section{Sample}

In this study, using a purposive sample type. Because the sample selected by the researcher is based on the criteria determined by the researcher. The criteria in selecting the sample used by the researcher are property, real estate \& building cost construction companies listed on the Indonesia Stock Exchange since 2013 and property, real estate \& building construction companies. which is included in the LQ45 index for the period February to July 2020.

Table 1

Sample Companies Under Study

\begin{tabular}{|c|l|l|}
\hline No & \multicolumn{1}{|c|}{ Kode Emiten } & \multicolumn{1}{c|}{ Nama Perusahaan } \\
\hline 1 & BSDE & PT. Bumi Serpong Damai, Tbk. \\
\hline 2 & CTRA & PT. Ciputra Development, Tbk. \\
\hline 3 & PTPP & PT. PP (Persero), Tbk. \\
\hline 4 & PWON & PT. Pakuwon Jati, Tbk. \\
\hline 5 & WIKA & PT. Wijaya Karya (Persero), Tbk. \\
\hline 6 & WSKT & PT. Waskita Karya (Persero), Tbk. \\
\hline
\end{tabular}

Source: www.idnfinancial.com

\section{Operationalization of Variables}

Table 2

Operationalization of Variables

\begin{tabular}{|c|c|l|}
\hline No & \multicolumn{1}{|c|}{ Variabel Penelitian } & \multicolumn{1}{c|}{ Rumus } \\
\hline 1 & Current Ratio (CR) (X1) & $\begin{array}{l}\text { Current Ratio (CR) = Total Aset Lancar / Total } \\
\text { Utang Lancar }\end{array}$ \\
\hline 2 & Debt to Equity Ratio (DER) (X2) & $\begin{array}{l}\text { Debt to Equity Ratio (DER) = Total Utang / Total } \\
\text { Ekuitas }\end{array}$ \\
\hline 3 & Net Profit Margin (NPM) (X3) & $\begin{array}{l}\text { Net Profit Margin (NPM) = Laba Bersih Setelah } \\
\text { Pajak / Penjualan Bersih }\end{array}$ \\
\hline
\end{tabular}




\begin{tabular}{|c|c|c|}
\hline 4 & Return on Equity $\quad($ ROE $)(X 4)$ & $\begin{array}{l}\text { Return on Equity }(R O E)=\text { Laba Bersih Setelah Pajak } \\
\text { / Total Modal }\end{array}$ \\
\hline 5 & Earning per Share (EPS) (X5) & $\begin{array}{l}\text { Earning per Share (EPS) = Laba yang diatribusikan } \\
\text { kepada pemilik perusahaan / Rata-rata tertimbang } \\
\text { saham beredar. }\end{array}$ \\
\hline 6 & Nilai Perusahaan $(\mathrm{PBV})(\mathrm{Y})$ & $\begin{array}{l}\text { Nilai Perusahaan (PBV) = Harga per lembar saham } \\
\text { diakhir tahun / Nilai Buku per lembar Saham } \\
\text { Nilai Buku per lembar Saham (BVPS) = Ekuitas } \\
\text { yang dapat diatribusikan kepada pemilik perusahaan / } \\
\text { Jumlah rata-rata saham tertimbang }\end{array}$ \\
\hline
\end{tabular}

Source : Author

\section{Regression Model Test Results}

In this study, the authors have tested the regression model, with the following results:

1. Chow test

Table 3

Result of Chow Test

\begin{tabular}{|c|c|c|c|}
\hline \multicolumn{4}{|c|}{ Redundant Fixed Effects Tests } \\
\hline \multicolumn{4}{|c|}{ Equation: Untitled } \\
\hline \multicolumn{4}{|c|}{ Test cross-section fixed effects } \\
\hline Effects Test & Statistic & d.f. & Prob. \\
\hline Cross-section F & 2.089426 & $(5,19)$ & 0.1115 \\
\hline Cross-section Chi-square & 13.144723 & 5 & 0.0221 \\
\hline
\end{tabular}

Source : Eviews 10

It can be seen from the results of the chow test in Table 3 above, where the results of the chow test with the fixed effect model meet the criteria. This can be seen from the chi-square probability value of 0.0221 which is smaller than 0.05 , so research with the regression model test using the Chow test shows that the model suitable for this study is the fixed effect model.

2. Hausman Test

Table 4

Result of Hausman Test

Correlated Random Effects - Hausman Test

Equation: Untitled

Test cross-section random effects

Prob. 


\section{Source : Eviews 10}

As seen in table 4, the results of the Hausman test with the random effect model meet the criteria. This can be seen from the results of the Hausman test value 0.0635 greater than 0.05 , so research with regression model testing using the Hausman test results that the model suitable for this study is the random effect model.

\section{Classical Assumption Test Results}

Before conducting multiple regression tests, this study conducted a classic assumption test first, to find out whether there were deviations from the requirements (assumptions) so that the processed data was feasible in the test, so that the regression model obtained in data processing was significant and representative. The classical assumption test is used to determine the condition of the data used in the study, including: normality test, multicollinearity test, autocorrelation test, and heteroscedasticity test. The following are the results of the classic assumption test processed using the Eviews 10 application:

\section{Normality Test Results}

The normality test is used to test whether the residual value resulting from regression is normally distributed or not. (Ghozali, 2017, 145) In this test the dependent variable (Y) uses the $\log$ formula, because there is data that has an extreme value, namely variable $\mathrm{X} 4$, so that To avoid the occurrence of abnormalities in the data, the log formula is used for the dependent variable. The normality test aims to test whether the regression model, the dependent variable, the independent variable, or both have a normal distribution or not (Hanitha 2020, 51). The following are the results of the normality test that has been carried out:

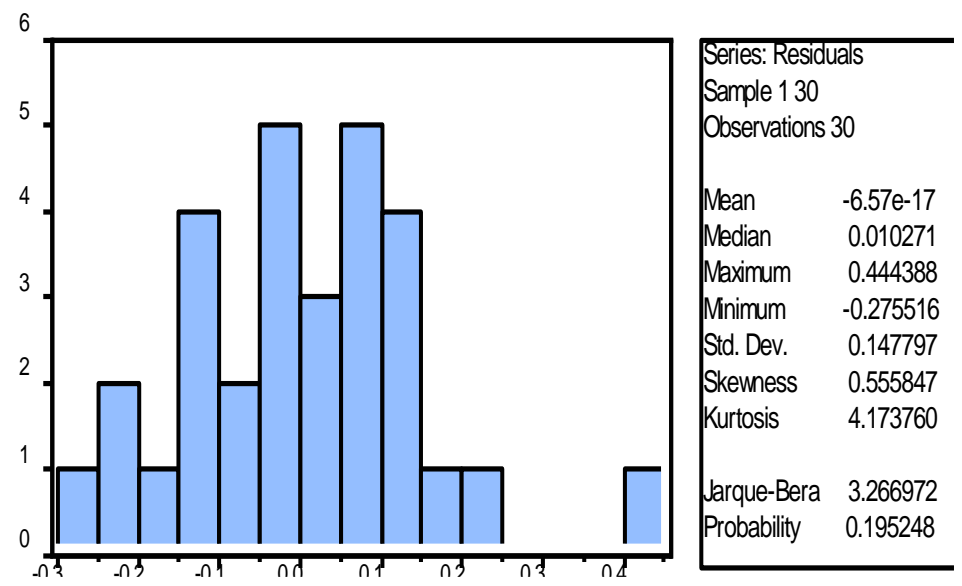

Figure 2

Normality Test

Source : Eviews 10

From Figure 2 it can be seen that the results of the normality test that the probability has a value of $0.195248>0.05$, it can be said that the data is normally distributed. 


\section{Multicollinearity Test Results}

According to (Gujarati, 2004) in the book (Wahyudi 2016, 142) says that if the correlation between two independent variables exceeds 0.8 then multicollinearity becomes a serious problem. If the correlation between the explanatory variables is not greater than the correlation of the dependent variable with each explanatory variable, it can be said that there is no serious problem. Thus, it can be concluded that if the correlation number is smaller than 0.8 , it can be said to have been free from multicollinearity problems.

The following are the results of the multicollinearity test that has been carried out in this study using the Eviews 10 data processing application:

Table 5

Hasil Uji Muktikolinearitas

\begin{tabular}{|c|c|c|c|c|c|}
\hline & $\mathrm{CR} \_\mathrm{X} 1$ & DER_X2_ & NPM_X3_ & ROE_X4_ & EPS_X5 \\
\hline $\mathrm{CR} \quad \mathrm{X} 1$ & 1.000000 & -0.554525 & 0.465011 & -0.229211 & -0.167113 \\
\hline DER_X2 & -0.554525 & 1.000000 & -0.643738 & 0.233386 & 0.365510 \\
\hline NPM_X3 & 0.465011 & -0.643738 & 1.000000 & 0.521824 & -0.160854 \\
\hline ROE_X4_ & -0.229211 & 0.233386 & 0.521824 & 1.000000 & 0.112949 \\
\hline EPS_X5_ & -0.167113 & 0.365510 & -0.160854 & 0.112949 & 1.000000 \\
\hline
\end{tabular}

Source: Eviews 10

Based on the multicollinearity test results in table 5 above, it can be interpreted that the proposed regression model does not have multicollinearity symptoms because the correlation value is $<0.8$. So that it can be used for the next regression analysis.

\section{Autocorrelation Test Results}

In this autocorrelation test, it aims to determine whether or not there is a correlation between confounding variables in a certain period and the previous variable (Ghozali 2017, 71) To detect the presence or absence of autocorrelation in this study using Durbin-Watson. The following are the results of the autocorrelation test from this study:

Table 6

Autocorrelation Test Results

\begin{tabular}{|l|l|}
\hline Durbin-Watson stat & 0.948473 \\
\hline
\end{tabular}

Source: Eviews 10

Based on table 6 above, it can be seen that the Durbin-Watson result is 0.948473 . The results of the study refer to the Durbin-Watson criteria, namely if the D-W number is between -2 and +2 , it means that there is no autocorrelation. Therefore, it means that this study does not occur autocorrelation. Then it can be used for further analysis.

\section{Heteroscedasticity Test Results}

This heteroscedasticity test examines the occurrence of residual variance differences from one observation period to another. (Ghozali 2017, 85) In this study, using the Glesjer test. 
Table 7

Heteroscedasticity Test Results

Heteroskedasticity Test: Glejser

\begin{tabular}{lclc} 
F-statistic & 0.623994 & Prob. F(5,24) & 0.6830 \\
Obs*R-squared & 3.451300 & Prob. Chi-Square(5) & 0.6308 \\
$\begin{array}{l}\text { Scaled explained } \\
\text { SS }\end{array}$ & 3.091476 & Prob. Chi-Square(5) \\
\hline
\end{tabular}

Source: Eviews 10

From the table above, it can be seen that the results of the Glesjer test in this study, that the Obs * R-squared value has a Chi-Square probability value of 0.6308 , the value is above 0.05 . Therefore, it shows that there is no heteroscedasticity problem in this study.

\section{Multiple Regression Analysis}

Multiple regression analysis is used to obtain the best regression equation between the independent variable and the dependent variable. The following are the results of multiple regression analysis tests that have been carried out in this study:

\section{Table 8}

\section{Multiple Regression Analysis}

Dependent Variable: PBV_Y

Method: Panel EGLS (Cross-section random effects)

Date: 07/14/20 Time: 13:10

Sample: 20142018

Periods included: 5

Cross-sections included: 6

Total panel (balanced) observations: 30

Swamy and Arora estimator of component variances

Variable

C

2.578289
Std. Error

t-Statistic

Prob. 


\begin{tabular}{ccccc} 
CR_X1 & -0.489857 & 0.472407 & -1.036939 & 0.3101 \\
DER_X2 & 0.579560 & 0.470463 & 1.231892 & 0.2299 \\
NPM_X3 & 0.588365 & 3.754844 & 0.156695 & 0.8768 \\
ROE_X4 & 7.005469 & 9.597021 & 0.729963 & 0.4725 \\
EPS_X5 & -0.010527 & 0.002370 & -4.440655 & 0.0002 \\
\hline
\end{tabular}

Source: Eviews $1 \overline{0}$

From the results of the data processing above, it can be seen that the regression model is:

$\mathrm{PBV}=2.578289-0.489857 \mathrm{CR}+0.0579560 \mathrm{DER}+0.588365 \mathrm{NPM}+7.005469 \mathrm{ROE}-0.010527$

EPS

Information :

$\mathrm{Y}=\mathrm{PBV}$ (Price to Book Value)

$\mathrm{X} 1=\mathrm{CR}$ (Current Ratio)

$\mathrm{X} 2=$ DER (Debt to Equity Ratio)

X3 = NPM (Net Profit Margin)

$\mathrm{X} 4=\mathrm{ROE}$ (Return on Equity)

X5 $=$ EPS (Earning per Share)

$\mathrm{e}=$ error

From the results of the $t$ statistical test and multiple linear regression equations, it can be described as follows:

a. A constant value of 2.578289 shows that if the independent variable, namely Current Ratio (CR), Debt to Equity Ratio (DER), Net Profit Margin (NPM), Return on Equity (ROE), Earning per Share (EPS) is zero, then the dependent variable namely the company value (Price to Book Value / PBV) is 2.578289 units.

b. The value of the Current Ratio (CR) coefficient of -0.489857 shows that if there is an increase in Current Ratio (CR) of 1 unit, it will reduce the company value (Price to Book Value / PBV) by 0.489857 units. Therefore, Current Ratio (CR) has a negative effect on firm value (Price to Book Value / PBV) in Property, Real Estate and Building Construction sector companies listed on the Indonesia Stock Exchange for the period 2014 - 2018.

c. The coefficient value of Debt to Equity Ratio (DER) of 0.579560 indicates that if there is an increase in Debt to Equity Ratio (DER) of 1 unit, it will increase the firm value (Price to Book Value / PBV) of 0.579560 units. So it can be interpreted that Debt to Equity Ratio (DER) has a positive effect on firm value (Price to Book Value / PBV) in Property, Real Estate and Building Construction sector companies listed on the Indonesia Stock Exchange for the period $2014-2018$.

d. The coefficient value of Net Profit Margin (NPM) of 0.588365 indicates that if there is an increase in Net Profit Margin (NPM) by 1 unit, it will increase the company value (Price to Book Value / PBV) by 0.588365 units. So it can be interpreted that Net Profit Margin (NPM) has a positive influence on firm value (Price to Book Value / PBV) in Property, Real Estate and Building Construction sector companies listed on the Indonesia Stock Exchange for the period 2014 - 2018.

e. The Return on Equity (ROE) coefficient value of 7.005469 shows that if there is an increase in Return on Equity (ROE) by 1 unit, it will increase the company value (Price to Book Value / PBV) by 7.005469 units. So it can be interpreted that Return on Equity (ROE) has a positive influence on company value (Price to Book Value / PBV) in Property, Real Estate and Building Construction sector companies listed on the Indonesia Stock Exchange for the period 2014 - 2018. 
f. The value of the Earning per Share (EPS) coefficient of -0.010527 shows that if there is an increase in Earning per Share (EPS) by 1 unit, it will reduce the company value (Price to Book Value / PBV) by -0.010527 units. So it means that Earning per Share (EPS) has a negative effect on firm value (Price to Book Value / PBV) in Property, Real Estate and Building Construction sector companies listed on the Indonesia Stock Exchange for the period 2014 - 2018.

\section{Test of Significance of Individual Parameters ( $t$ test)}

The $t$ test is used to determine whether partially the independent variable has a significant effect on the dependent variable with a significance level of 0.05 . The following are the results of the $t$ test that was carried out in this study:

Based on the results in table 8 , in this study the number of observational data is 30 and 5 independent variables and 1 independent variable, meaning that the degree of freedom (df) value is 24 , so the t table has a value of 2.06390 and it can be concluded that partially only the EPS variable is has a significant influence on firm value (PBV)

\section{Simultaneous Significance Test (Test F)}

Simultaneous significance test (Test F) is used to test the significance of the effect of several independent variables on the dependent variable. The significance level is 0.05 , if it is smaller than 0.05 then $\mathrm{HO}$ is rejected, on the contrary, if it is greater than 0.05 then $\mathrm{H} 0$ is accepted. The number of observation data in this study was 30 and the number of variables was 6 , which means that the value of the degree of freedom of the numerator (df1/ N1) is 5 and the degree of freedom of the denominator (df2 / N2) is 24 , then the value of the F table is 2.62. The following test criteria are used to reject or accept the hypothesis by looking at the test results in the following table:

Table 9

Simultaneous Significance Test (Test F)

\begin{tabular}{|l|r|}
\hline F-statistic & 6.497211 \\
\hline Prob(F-statistic) & 0.000595 \\
\hline Source: Eviews 10
\end{tabular}

Based on the results of the F test in Table 10 in the Least Square Panel model, it can be seen that the results of the effect of the five independent variables simultaneously show an F-statistic value of $6.497211>$ an $\mathrm{F}$ table value of 2.62 with a probability of $0.000595<0.05$. It can be concluded that all independent variables in this study, namely Current Ratio, Debt to Equity Ratio, Net Profit Margin, Return on Equity, and Earning per Share together have a significant effect on the dependent variable, namely firm value (Price to Book Value).

\section{Coefficient of Determination}

The coefficient of determination is used to calculate the ability of the model to explain the variation in the dependent variable. (Ghozali 2017, 56) The coefficient of determination is between zero and one. 
Table 10

Coefficient of Determination

\begin{tabular}{|l|l|}
\hline R-squared & 0.575116 \\
\hline Adjusted R-squared & 0.486599 \\
\hline
\end{tabular}

Source: Eviews 10

Based on the results in table 10, it shows that the adjusted value is 0.486599 , which means that the variation of the five independent variables (X), namely Current Ratio, Debt to Equity Ratio, Net Profit Margin, Return on Equity, and Earning per Share are able to explain $48.66 \%$ of the variation in the dependent variable ( Y) is the company value (Price to Book Value). While the remaining $51.34 \%$ is explained by other variables not examined in this study.

\section{Discussion}

1. Effect of Current Ratio on firm value (Price to Book Value)

The first hypothesis is that the Current Ratio has a negative and insignificant effect on firm value (Price to Book Value) in the Property, Real Estate and Building Construction sector companies listed on the Indonesia Stock Exchange for the period 2014-2018. The results of this study are in line with the results of the study (Rizka and Mochammad, 2017) which states that the Current ratio has a negative and insignificant effect on Price to Book Value. This can be due to the fact that current assets are considered to be used more to pay off short-term debt than for operations, but this does not significantly affect the value of the company, meaning that investors do not only see the company's Current Ratio in making their investments.

2. The effect of Debt to Equity Ratio on firm value (Price to Book Value)

The second hypothesis is that the Debt to Equity Ratio has a positive and insignificant effect on the firm value (Price to Book Value) in the Property, Real Estate and Building Construction sector companies listed on the Indonesia Stock Exchange for the period 20142018. The results of this study are the same as the results of the study ( Priska, Ivonne, and Reitty, 2019) who state that the Debt to Equity Ratio has no significant effect on Price to Book Value. This can happen, because the greater the Debt to Equity Ratio, the better the company's operational activities so that creditors' trust to lend their funds increases, this can be a signal for investors to invest their capital due to the belief that the company can grow better and this is which increases company value. In this study, insignificance can be caused because investors do not only see the debt and equity components.

3. Effect of Net Profit Margin on company value (Price to Book Value)

The third hypothesis is that Net Profit Margin has a positive and insignificant effect on firm value (Price to Book Value) in Property, Real Estate and Building Construction sector companies listed on the Indonesia Stock Exchange for the period 2014 - 2018. This is not in line with the research conducted ( Idha, Dwiatmanto, and Devi, 2015) namely Net Profit Margin has a significant positive effect on firm value (Price to Book Value). This may occur because the higher the company is able to produce a high net profit margin, the investors will have confidence in the company in carrying out its operations, so that it can increase company value. But insignificance can be caused because investors are not only concerned with profit in valuing a company.

4. Effect of Return on Equity on firm value (Price to Book Value)

The fourth hypothesis is that Return on Equity has a positive and insignificant effect on firm value (Price to Book Value) in Property, Real Estate and Building Construction sector companies listed on the Indonesia Stock Exchange for the period 2014-2018. This research is not the same as the research conducted by Priska Sondakh, Ivonne Saerang, Reitty Samadi 
(2019) who have the results of Return on Equity have a significant effect on firm value. Return on Equity can positively affect firm value because if profit increases ROE will increase, so that firm value will also increase. But this study does not have a significant effect because investors are not only concerned with profit in assessing a company.

5. The effect of Earning per Share on firm value (Price to Book Value)

The fifth hypothesis is that Earning per Share has a significant negative effect on firm value (Price to Book Value) in Property, Real Estate and Building Construction sector companies listed on the Indonesia Stock Exchange for the period 2014 - 2018. This research has similarities with research (Sukma and Teguh). , 2014), (Faradila, Ari, and Rita, 2017) in terms of the negative effect of Earning per Share on firm value (Price to Book Value), but in terms of significance this research has a significant effect, while research (Maman and Rikha, 2015), (Faradila, Ari, and Rita, 2017) have no significant effect of Earning per Share on firm value (Price to Book Value). This means that in this study, it is not certain that all the profits contained in each share come from the company's operational results but from the sale of assets that support the company's operational activities (machines, production equipment, etc.) so that it can make the company's performance decrease and not necessarily. The entire earnings per share is distributed among shareholders, thereby making the company unattractive to investors.

6. Simultaneous influence of Current Ratio, Debt to Equity Ratio, Net Profit Margin, Return on Equity, and Earning per Share on firm value (Price to Book Value)

The sixth hypothesis is that Current Ratio, Debt to Equity Ratio, Net Profit Margin, Return on Equity, and Earning per Share simultaneously have a significant influence on firm value (Price to Book Value) in Property, Real Estate and Building Construction sector companies listed in Indonesia Stock Exchange for the period 2014 - 2018. With an adjusted value (amounting to 0.486599 , which means the variation of the five independent variables (X), namely Current Ratio, Debt to Equity Ratio, Net Profit Margin, Return on Equity, and Earning per Share, is able to explain $48.66 \%$ of variable variations. dependent (Y), namely the value of the company (Price to Book Value), while the remaining 51.34\% is explained by other variables not examined.

\section{Conclusion}

1. This research was conducted with the aim to determine the effect of Current Ratio, Debt to Equity Ratio, Net Profit Margin, Return on Equity, \& Earning per Share on company value in the Property, Real Estate and Building Construction sector companies listed on the Indonesia Stock Exchange in 2014. - 2018. In this study, a sample of six companies were selected based on predetermined criteria. From the results of the analysis and discussion that has been carried out, several conclusions were obtained from this study, namely:

2. From the analysis of variable X1, namely Current Ratio, has a significance of $0.3101>0.05$, which means that $\mathrm{H} 1$ is rejected. Then these results prove that the Current Ratio has a negative and insignificant effect on firm value.

3. From the analysis of variable X2, namely the Debt to Equity Ratio has a significance of 0.2299>0.05, which means that $\mathrm{H} 2$ is rejected. Then these results prove that the Debt to Equity Ratio does not have a significant positive effect on firm value.

4. From the analysis of variable X3, namely Net Profit Margin, has a significance of 0.8768> 0.05 , which means that $\mathrm{H} 3$ is rejected. Then these results prove that the Net Profit Margin has a positive and insignificant effect on firm value.

5. From the analysis of variable X4, namely Return on Equity has a significance of 0.4725> 0.05, which means that $\mathrm{H} 4$ is rejected. Then these results prove that Return on Equity has a positive and insignificant effect on firm value. 
6. From the analysis of variable X5, namely Earning per Share has a significance of 0.0002 $<0.05$, which means that $\mathrm{H} 5$ is accepted. Then these results prove that Earning per Share has a significant negative effect on firm value.

7. From the results of the simultaneous analysis between all independent variables $(\mathrm{X})$ on the dependent variable (Y), where all $\mathrm{X}$ variables in this study are Current Ratio (X1), Debt to Equity Ratio (X2), Net Profit Margin (X3), Return on Equity (X4) and Earning per Share (X5) were simultaneously tested against the Y variable, namely the firm value (Price to Book Value). With an adjusted result of 0.486599 , which means that the variation of the independent variables in this study, namely Current Ratio, Debt to Equity Ratio, Net Profit Margin, Return on Equity, and Earning per Share is able to explain $48.66 \%$ of variations in the dependent variable, namely firm value (Price to Book Value). ). While the remaining $51.34 \%$ is explained by other variables not examined in this study. Therefore H6 is accepted, thus proving that Current Ratio, Debt to Equity Ratio, Net Profit Margin, Return on Equity \& Earnig per Share simultaneously have an influence on firm value.

\section{Suggestion}

Based on this research, the authors can provide suggestions aimed at further researchers. The following is a description of the author's suggestions:

1. Academic Advice

a. The author hopes that this research can be used for further research.

b. The writer hopes that further researchers will develop this research again by adding other variables related to firm value.

c. The author hopes that this research can be developed by further researchers with other corporate sectors.

2. Practical Suggestions

Practical advice from this research is to conduct research, please pay more attention to company management in running its business. Companies that have good efficiency and are able to smoothly pay their obligations to creditors and also have fluency in operational activities and have a good cash turnover, so that no idle funds are too large, reflecting good performance, they will have more good corporate value in the eyes. Investors

\section{BIBLIOGRAPHY}

Annisa,Rikza dan M. Chabachib.-Analisis Pengaruh Current Ratio (CR), Debt to Equity Ratio (DER), Return On Assets (ROA) terhadap Priceto Book Value (PBV), dengan Dividend Payout Ratiosebagai Variabel Intervening.(Studi Kasus pada Perusahaan Industri Manufaktur yang Terdaftar di BEI Periode 2011-2014)\|, Diponogoro Journal Of Management.2017, 13, hal. 1-15.

Andy. (2018). Pengaruh Return on Assets, Debt To Equity Ratio, Debt To Assets Ratio, Ukuran Perusahaan Dan Deferred Tax Expense Terhadap Tax Avoidance. Primanomics : Jurnal Ekonomi Dan Bisnis - Vol. 16. No. 2 (2018), 16(2).

Bungin,Burhan. Metodologi Penelitian Kuantitatif. Jakarta: Kencana, 2017.

Faradila W. R., Ari P., dan Rita A. -Pengaruh EPS, Ukuran Perusahaan, Profitabilitas, Leverage, Sales Growth, dan Kebijakan Dividen terhadap Nilai Perushaan pada Industri Makanan dan Minuman yang Terdaftar di Bursa Efek Indonesia Tahun 2010-2015||, Jurnal Ekonomika dan Bisnis. 2017, 13, hal 1-15.

Hanitha, V. (2020). The Effect of Excellent Services and Corporate Images to Customer

Satisfaction on Financial Banking Sectors. eCo-Buss, 51. 
Hartono. Konsep Analisa Laporan Keuangan Dengan Pendekatan Rasio dan SPSS. Sleman: CV Budi Utama, 2018.

Hatmawan, Slamet R., dan Aglis A.Metode Riset Penelitian Kuantitatif Penelitian Dibidang Manajemen, Teknik, dan Eksperimen. Yogyakarta: CV Budi Utama, 2020.

Hery. Pengantar Akuntansi. Jakarta: PT Grasindo,2015.

Idha A. A., Dwiatmanto, dan Devi F. A. -Pengaruh Return On Equity, Net Profit Margin, Debt to Equity Ratio, dan Long Term Debt to Equity Ratio terhadap Price to Book Value (Studi Pada Perusahaan Sub Sektor Makanan dan Minuman yang Terdaftar di Bursa Efek Indonesia Periode Tahun 2010-2013)||, Jurnal Administrasi Bisnis. Oktober 2015, 7 , hal 1-8.

Indrarini, Silvia. Nilai Perusahaan Melalui Kualitas Laba. Surabaya: Scopindo Media Pustaka, 2019.

Iswati, Muklis A., dan Sri. Metodologi Penelitian Kuantitatif. Surabaya: Airlangga University Press, 2017.

Jatmiko, dan Dadang P. Pengantar Manajemen Keuangan. Yogyakarta: Diandra Kreatif, 2017.

Junaidi. Titik Persentase Distribusi f (Probabilita $=0.05$ ). 2010. https://junaidichaniago.files.wordpress.com/2010/04/tabel-f-0-05.pdf(Diakses tanggal 22 Juni 2020).

Pambuko, Zulfikar A., dan Nuryanto.Eviews Untuk Analisis Ekonometrika Dasar: Aplikasi dan Interprestasi . Magelang: UNIMMA PRESS, 2018.

Priska S., Ivonne S., dan Reitty Samadi. -Pengaruh Struktur Modal (ROE,ROA dan DER) terhadap Nilai Perusahaan (PBV) pada Perusahaan Sektor Properti yang Terdaftar di BEI (Periode 2013-2016)||, Jurnal EMBA. Juli 2019, 3086, hal 3079-3088.

Purnama, M. (2019). Pengaruh QR, DER, NPM, ITO Terhadap Pertumbuhan Laba pada Perusahaan Keramik, Porselen, dan Kaca Tahun 2008-2017. GOODWILL, 121.

Purnama, M. P. (2020). Pengaruh Likuiditas, Profitabilitas, dan Pertumbuhan Aset terhadap Struktur Modal (Studi pada PT. Indofood Sukses Makmur, Tbk. yang Terdaftar di Bursa Efek Indonesia pada Periode Tahun 2010-2017). eCo-Buss , 19.

Sugeng, dan Bambang. Manajemen Keuangan Fundamental. Sleman: DEEPUBLISH (Grup Penerbitan CV Budi Utama), 2017.

Sujarweni, V. Wiratna. Metodologi Penelitian Bisnis \& Ekonomi. Yogyakarta: Pustaka Baru, 2015.

Sukamulja, Sukmawati. Analisis Laporan Keuangan sebagai Dasar Pengambilan Keputusan Investasi. Yogyakarta: ANDI dengan BPFE, 2019.

Suryaman, Maman dan Rikha Muftia K. -Pengaruh Debt to Equity Ratio (DER), Return On Asset (ROA), dan Earning per Share (EPS) terhadap Price to Book Value (PBV) pada Perusahaan Telekomunikasi yang Terdaftar di Bursa Efek Indonesia Periode 20092013\|, Jurnal Fokus. Maret 2015, 42, hal 34-44.

Widyatuti, Maria. Analisa Kritis Laporan Keuangan. Surabaya: Jakad Media Nusantara, 2017. . Indeks LQ45 Februari-Juli 2020. 2020. https://www.idx.co.id/data-pasar/datasaham/indeks-saham/

(Diakses tanggal 22 Juni 2020).

.Daftar Perusahaan Sektor Property, Real Estate \& Building Construction

$\begin{array}{llllll} & \text { terdaftar } & \text { di } & \text { Bursa }\end{array}$

https://www.idnfinancials.com/id/company/sector/property-real-estate-and-building-

construction-7 (Diakses tanggal 22 Juni 2020).

. Laporan Keuangan PT. Bumi Serpong Damai, Tbk. Tahun 2018.

https://www.idnfinancials.com/id/bsde/pt-bumi-serpong-damai-tbk\#financial-data 
(Diakses tanggal 22 Juni 2020).

Histori harga saham. 2020. HYPERLINK "https://finance.yahoo.com/quote/" https://finance.yahoo.com/quote. (Diakses tanggal 22 Juni 2020).

www.idx.co.id 